\title{
Archaeological Monitoring and Testing at the Catalpa-Pershing Storm Drainage Project in San Antonio, Texas
}

Anne A. Fox

Elizabeth C. Frkuska

Follow this and additional works at: https://scholarworks.sfasu.edu/ita

Part of the American Material Culture Commons, Archaeological Anthropology Commons, Environmental Studies Commons, Other American Studies Commons, Other Arts and Humanities Commons, Other History of Art, Architecture, and Archaeology Commons, and the United States History Commons

Tell us how this article helped you.

This Article is brought to you for free and open access by the Center for Regional Heritage Research at SFA ScholarWorks. It has been accepted for inclusion in Index of Texas Archaeology: Open Access Gray Literature from the Lone Star State by an authorized editor of SFA ScholarWorks. For more information, please contact cdsscholarworks@sfasu.edu. 


\section{Archaeological Monitoring and Testing at the Catalpa-Pershing Storm Drainage Project in San Antonio, Texas}

\section{Creative Commons License}

\section{(c) (1) \&}

This work is licensed under a Creative Commons Attribution-NonCommercial 4.0 International License 


\section{ARCHAEOLOGICAL MONITORING AND TESTING AT \\ THE CATALPA-PERSHING STORM DRAINAGE PROJECT \\ IN SAN ANTONIO, TEXAS}

Anne A. Fox and Elizabeth C. Frkuska

Center for Archaeological Research

The University of Texas at San Antonio

Archaeological Survey Report, No. 48

1978 
INTRODUCTION. . . . . . . . . . . . . . . . 1

PART I: Archaeological Monitoring (Anne A. Fox) . . . 2

PART II: Test Excavations at 41 BX 322 (Elizabeth $C$.

Frkuska)................ 4

Introduction ............ . . 4

Previous Archaeological Work ......... . 4

The Site............. 6

Field Investigations . . . . . . . . . 6

Summary .............. . . 7

REFERENCES CITED. . . . . . . . . . . . . . . 8

FIGURE

1. Map of Project Area Showing the Location

of Site 41 BX 322.......... 5 


\section{INTRODUCTION}

In Feburary 1977, the Center for Archaeological Research was contracted by the City of San Antonio Department of Parks and Recreation to conduct observation and limited testing in the immediate area of the Catalpa-Pershing Drainage Project in Brackenridge Park. The affected area within the park had previously been surveyed for archaeological sites by Center personnel in connection with a general historic and prehistoric survey of the park as a whole (Fox and Katz 1978) in preparation for the proposed Master Plan. During the initial survey, one historic site and two prehistoric sites were recorded in the area through which the drainage project is to be constructed.

Of these three sites, only one (41 BX 322) appeared to be threatened by drainage ditch excavations. Recommendations were made to test the $41 \mathrm{BX} 322$ site, and this was undertaken in December 1977.

The following report, presented in two parts, describes the results of the drainage ditch excavation monitoring and subsequent site testing.

The archaeological monitoring of the Catalpa-Pershing project, was done by Anne A. Fox. The subsequent testing of site 41 BX 322 was done by Augustine Frkuska, Jr., Elizabeth Frkuska and Margarita Vazquez, under the supervision of Anne A. Fox. All field work was done under the direction of Dr. Thomas R. Hester, Director, and Jack D. Eaton, Assistant Director, Center for Archaeological Research, The University of Texas at San Antonio. 


\section{PART I}

ARCHAEOLOGICAL MONITORING

Anne A. Fox

The first site to be affected was at the south end of the project, on a Spanish land grant acquired in 1823 by Jose Antonio de la Garza, who subsequently constructed a grist mi11 on his property (Barnes 1910:244). Since the exact location of the Garza mi11 is not known, it was necessary to monitor excavation for the drainage ditch through the Garza property to insure that any indications of historic structures would be properly recorded and as much information as possible salvaged. The author was present during the time of primary excavation of this section of the ditch. No evidence of the mill was found, which could mean either that the mill was located farther downstream or that early golf course construction eliminated all traces of the structure.

While observing the ditch excavations, the author also inspected the two prehistoric archaeological sites which are located farther upstream along the ditch. It was determined that site 41 BX 321 is just outside the area to be excavated and will not be disturbed. Site 41 BX 322, however, appeared to be threatened by ditch excavations and relocation of the miniature train track. The test excavations reported below were recommended in order to assess the extent and importance of the site and to determine if mitigation would be necessary.

The entire plan for ditch excavations was examined to determine if other known historic or prehistoric sites would be affected in the Mahncke Park area, to the east of Brackenridge Park. Copies of original City plats were obtained to determine exactly where the proposed ditch crossed the route of the Alamo 
Acequia which was located east of Broadway, within Mahncke Park. Careful examination of the area confirmed that no visible trace of the original acequia remains within the park, and that no damage will be done to the acequia by the proposed modifications. 
PART II

TEST EXCAVATIONS AT 41 BX 322

Elizabeth C. Frkuska

Introduction

In December 1977, an archaeological field team from the Center for Archaeological Research, The University of Texas at San Antonio, directed by Paul and Susanna Katz, located prehistoric site 41 BX 322 during a survey of Brackenridge Park (Fox and Katz 1978). The center of the site is located approximately 275 meters east of the San Antonio River and 55 meters west of the Brackenridge Park drainage ditch which is parallel to Avenue B (Fig. 1).

In order to further evaluate the site, limited test excavations were recommended at 41 BX 322. Under contract between the Center for Archaeological Reseach and the City of San Antonio Department of Parks and Recreation, a one-day project of 7 imited test excavations at the site was conducted in July 1977. The field crew consisted of Augustine Frkuska, Jr., Elizabeth Frkuska and Margarita Vazquez, under the supervision of Anne A. Fox.

Previous Archaeological Work

Previous archaeological work done in this area includes a survey of the $01 m o s$ Basin (Fox 1975), excavations at Incarnate Word College in the summer of 1976 by Katz (unpublished), and the December 1976 site survey of Brackenridge Park undertaken by Paul and Susanna Katz (Fox and Katz 1978). C. D. Orchard also has extensive collections from the area (Orchard and Campbe11 1954). 
This page has been

redacted because it

contains restricted

information. 
The Site

Site 41 BX 322 lies on a floodplain of the San Antonio River in a moderate to heavily forested area. Current vegetation on the site includes oak, pecan, bamboo and various grasses. Also noted on the surface of the site as well as in test excavations were three distinct genera of freshwater gastropods: Polygyra, Helicina and Rabdotus.

The soil in the area is predominantly the Lewisville silty clay series which occurs in broad terraces along rivers and creeks (Taylor, Hailey and Richmonds 1966:25). Also closely associated with the site area are Trinity and Frio soils, typically found in floodplain regions (ibid.:32).

Site 41 BX 322 is approximately 180 meters 1 ong and 75 meters wide. The entire site area is traversed by horse trails which have exposed small amounts of burned chert debris, flakes and snail she11s. Lithic materials were noticed in low densities throughout the area, and no concentrations of lithic materials were evident. Diagnostic tools were not found during the present testing and survey program, although one scraping and/or cutting tool was collected during the original survey (Fox and Katz 1978). The site has probably been extensively collected over the years.

\section{Field Investigations}

Field work began with a surface survey of the site area to determine the best location for a test excavation. The area chosen for the $1 \mathrm{~m}^{2}$ test had the highest surface 1 ithic density although it was not a well-defined concentration. The test unit, Test $A$, was oriented north-south, approximately six meters west of the Brackenridge Eagle miniature railroad tracks (Fig. 1). The objective of the testing was to determine the extent of subsurface deposits. 
Arbitrary $10 \mathrm{~cm}$ levels were established, continuing for three levels to a depth of $30 \mathrm{~cm}$. A11 material excavated was screened through a 1/4-inch screen. The artifacts, notes and photographs taken during the project are on file at the Center for Archaeological Research.

Level 1 of test unit $A, 0-10 \mathrm{~cm}$ below the ground surface, contained a very dry gray clayey soil with little cultural material. Three fragments of modern glass were found along with 15 chert chunks and three interior flakes, one of which had been retouched. Three Helicina snail shells were also recovered.

Level $2(10-20 \mathrm{~cm})$ was a dark brownish gray soil, more moist than the previous level and intermixed with caliche fragments. Eight chert chunks and one secondary flake were recovered. Al1 three varieties of gastropod shells previously mentioned were also recovered.

Since only one artifact was recovered in the previous level, only the south half of test unit $A$ was taken down to the $30 \mathrm{~cm}$ level. This level consisted of a medium to dark brown soil, clayey and moist, with intermixed caliche pebbles. Nine chert chunks and three interior flakes were recovered.

\section{Summary}

The JuTy 1977 test excavation supports Katz's suggestion that the area was a temporary campsite (Fox and Katz 1978) and was used infrequently in the prehistoric past. Since no diagnostic materials were recovered during surface survey or excavation, an age for the site cannot be determined. No further investigations at 41 BX 322 wi1l be necessary. 


\section{REFERENCES CITED}

Barnes, Charles Merritt

1910 Combats and Conquests of Immortal Heroes. Guessaz and Fuerlet, San Antonio.

Fox, Anne A.

1975 An Archaeological Assessment of the Southern Portion of the 01 mos Basin, Bexar County, Texas. The University of Texas at San Antonio, Center for Archaeological Research, Archaeological Survey Report 9.

Fox, Anne A. and Susanna R. Katz

1978 An Assessment of the Archaeological and Historical Resources in Brackenridge Park, San Antonio, Texas. The University of Texas at San Antonio, Center for Archaeological Research, Archaeological Survey Report 33.

Orchard, C. D. and T. N. Campbel1

1954 Evidences of Early Man from the Vicinity of San Antonio, Texas. Texas Journat of Science 6:454-465.

Taylor, F. B., R. B. Hailey and D. L. Richmonds

1966 Soil Survey, Bexar County, Texas. United States Department of Agriculture. The U. S. Government Printing Office, Washington, D.C. 